\title{
Ewy Lipskiej kłopot z samotnością. Od ogółu do szczegółu, czyli dedukowanie ja
}

Sebastian Brejnak

TEKSTY DRUGIE 2020, NR 5, S. 361-378

DOI: 10.18318/td.2020.5.22 | ORCID: 0000-0002-8681-5133

Wprowadzenie: logika samotności

Poezja jako wyraz samotności duszy i poety i styl poetycki tak samo. Mur kryształowy między poetą a ludźmi

Nie bez powodu swoje rozważania nad fenomenem samotności w twórczości Ewy Lipskiej rozpocząłem od przytoczenia jednego z aforyzmów Henryka Elzenberga uważanego przez Piotra Domerackiego ${ }^{1}$ - wiodącego polskiego przedstawiciela studiów nad samotnością i twórcy terminu „monoseologia” - za jednego z najwybitniejszych przedstawicieli filozofii samotności

1 Zob. P. Domeracki Elzenbergowski arystokratyzm ducha, w: Elzenberg - tradycja i współczesność, red. W. Tyburski, R. Wiśniewski, Wydawnictwo Naukowe UMK, Toruń 2009.

2 Czyli "nauce o samotności” (gr. monosé - samotność). Zob. P. Domeracki Horyzonty i perspektywy monoseologii. Filozoficzne studium samotności, Wydawnictwo Naukowe UMK, Toruń 2018.

3 Pojęcia zaczerpniętego m.in. z pism Emmanuela Lévinasa (Czas i to, co inne) oraz Mikołaja Bierdiajewa (Rozważania o egzystencji. Filozofia samotności i wspólnoty). Zob. P. Domeracki Horyzonty..., s. 76.

\section{Sebastian Brejnak}

- mgr, doktorant li-

teraturoznawstwa na Wydziale Polonistyki

Uj (Szkoła Doktorska

Nauk Humanistycz-

nych UJ). Publikował

m.in. ${ }_{\text {„Ruchu Lite- }}$

rackim" $i$ „Kontekstach

Kultury". Autor książki

Niepokój. Nowo-

czesność w świetle

anachronicznych

konfiguracji doświad-

czenia nieswojości

(2019). Obecnie

zajmuje się interpre-

tacją twórczości Ewy

Lipskiej w perspek-

tywie fenomenu

samotności.Kontakt:

sebastianbrejnak@

gmail.com 
W pewnych aspektach postawa podmiotu prezentującego się w Kłopocie z istnieniem wydaje się bliska sytuacji permanentnego „kłopotu” z samotnością podmiotowości wielu utworów Lipskiej. Co i rusz boryka się z nim także czytelnik twórczości autorki Pogłosu, przytłoczony „przepychem samotności” ${ }^{4}$ w światach kreowanych przez poetkę, w których s a ma s a mo t n o ść prezentuje się na wskroś idiomatycznie, często wbrew intuicyjnemu rozumieniu.

Jeśli więc z pewnością nie da się - w odniesieniu do prywatnego słownika Lipskiej - stworzyć jednej zadowalającej definicji „samotności”, to trudno nie zgodzić się ze stwierdzeniem, że sam fenomen samotności fascynuje poetkę od dawna. Mnogość utworów pochodzących z różnych faz twórczości Lipskiej zbudowanych na metaforyce, w której wiodącą rolę odgrywają takie pojęcia jak „pustynia”,,,samotność”/,"samotnia”,,,schron” (żeby wymienić tylko utwory: Poeta? Zbrodniarz? Szaleniec?, Zakon turystów, Powrót, Myjnia samochodowa, Poeta, Gdzie Indziej, Dom Spokojnej Starości, powieść Sefer czy dramat Nie o śmierć tutaj chodzi, lecz o biały kordonek), to dowód nie tylko na nieodzowność „kłopotu [Lipskiej] z samotnością", ale również świadectwo swego rodzaju ewolucji czy intensyfikacji tej problematyki w jej dorobku. W ostatniej dekadzie opublikowane zostały zresztą dwa wiersze zatytułowane Samotność (w tomie Miłość, droga pani Schubert z 2013 i Czytnik linii papilarnych z 2015 roku). Razem z, pochodzącym z tomiku Nie o śmierć tutaj chodzi, lecz o biaty kordonek (1982) utworem Moja samotność, tworzą one swoisty liryczny tryptyk z samotnością w roli głównej.

W niniejszym szkicu postaram się przyjrzeć bliżej właśnie tym trzem wierszom, traktując je jako przejaw szczególnej kondensacji refleksji Lipskiej nad samotnością. Spróbuję na podstawie tych próbek twórczości poetki zbadać logikę samotności autorki Stypendystów czasów, wychodząc z założenia, że prymarną przestrzenią samotności ${ }^{5}$ jest dla Lipskiej sama literatura/ twórczość (metonimizowana przez „poezję” jak u Elzenberga bądź „wiersz”, o którym poetka w jednym z listów do Stanisława Lema pisze, że jest to „metafizyczna kraina samotności"6). Przestrzeń ta stanowi ucho igielne (toż) samości podmiotu poszczególnych utworów, które pozwala mu na krytyczną autorefleksję, zanegowanie siebie i „wyprowadzenie” własnego j a na ścieżkę

E. Lipska Myjnia samochodowa, w: tejże Wiersze wybrane, Wydawnictwo a5, Kraków 2015, s. 34.

5 Albo "samotnością przestrzeni”: zob. E. Dickinson 1695, w: tejże Samotność przestrzeni, przeł. T. Sławek, Biuro Literackie, Stronie Śląskie 2019, s. 51.

E. Lipska, S. Lem Boli tylko, gdy się śmieje... listy i rozmowy, Wydawnictwo Literackie, Kraków 2018, s. 251. 
indywiduacji. Drogę, jaką pokonuje ów podmiot - od wspólnotowego n i e - ja do (ni e) ja jednostkowego - nazywam metaforycznie egzystencjalną dedukcją - przechodzeniem od bycia "osobnikiem ogólnym” do statusu "osobnika poszczególnego"7. Między tymi modusami bycia rozpościera się u Lipskiej Elzenbergowski „mur kryształowy” - deformujący wizerunek przeglądających się w nim „osobników” lub, inaczej - pryzmat, przez który nijaka, bezbarwna o s ob ow o ść przechodzi w pełnokrwistą, wielowymiarową o s obę.

\section{Wyprowadzanie (n ie)ja z "nieusatysfakcjonowania”}

Powracając do samego tytułu wprowadzenia, mianowicie do pojęcia „logiki samotności", trzeba wspomnieć, że posługuje się nim przywoływany już Piotr Domeracki.Za podstawowy mechanizm funkcjonowania samotności uznaje on relacyjność, co może wydać się na pozór paradoksalne. Domeracki wymienia cztery modelowe relacje, jakie mogą zachodzić między „jednym” (jednostką) a „wieloma” (wspólnotą, społeczeństwem, innymi). Są one następujące: „1) ja $i$ wiele, 2) ja $w$ wielu, 3) wiele $w$ jednym, 3) jedno $a$ wiele” ${ }^{\prime}$. Jak widać, decydujący jest tu spójnik/przyimek, określający wymiar zdystansowania jednostki względem zbiorowości oraz charakter partycypacji poszczególnego człowieka w życiu wspólnoty.

Pierwszy typ opisuje relację symbiozy i symetrycznej współzależności między ja i społeczeństwem. W drugim jednostka zostaje przez wspólnotowość zasymilowana, ginie w tłumie. Model trzeci określa sytuację, w której różnorodność zanika kosztem unifikacji, umasowienia jednostek. Relacja „jedno $a$ wiele” opiera się natomiast na „dysymilacji (rozpodobnieniu, zróżnicowaniu, dezintegracji)"9 - więź łącząca indywiduum ze społeczeństwem zostaje zerwana bądź z woli samej jednostki, bądź wskutek społecznej ekskluzji.

Pozornie tylko ostatni model można podporządkować egzystencjalnej sytuacji samotnika. Mikołaj Bierdiajew w Rozważaniach o egzystencji zwraca jednak uwagę, że każdy z wyżej wymienionych scenariuszy (choć w nieco

7 Nazwy "Osobnik ogólny " i "osobnik poszczególny" pojawiają się w poetyckim dramacie zamieszczonym w tomiku Osobnikt Krzysztofa Siwczyka (K. Siwczyk W pomroce, w: tegoż Osobnikt, Wydawnictwo a5, Kraków 2020).

8 P. Domeracki Horyzonty..., s. 78.

9 Tamże, s. 79. 
innym przebiegu) potencjalnie prowadzi do bycia-samotnym ${ }^{10}$, ponieważ może wiązać się z poczuciem alienacji. To natomiast, żeby tylko przypomnieć myśl Paula Tillicha - „stan egzystencji jest stanem wyobcowania”"11 - wydaje się niezbywalne w tzw. życiu autentycznym (pojmowanym egzystencjalistycznie). Jednostka mimetycznie/mimikrycznie rozproszona w tłumie („ja $w$ wielu”) bądź zdezindywidualizowana w procesie społecznej homogenizacji („wiele $w$ jednym"), a także: pozornie pozostająca ze społeczeństwem na równych prawach („ja $i$ wiele”) również może być bowiem narażona na osamotnienie (zwłaszcza samotność niemimowolną - „złą samotność"12).

Wydaje się, że właśnie tę wielowektorowość i aksjologiczno-poznawczą migotliwość „samotności” konceptualizuje Lipska w wielu swoich utworach, w których na żywym organizmie wiersza dokonuje się operacja „wy-prowadzania” (łac. de-ductio) j a z ni e-j a (lub: „my”) - z odjednostkowionego ogółu do poszczególności. W utworze Moja samotność widać ten proces najklarowniej:

Moja samotność ukończyła Szkołę Prymusów.

Jest punktualna i pilna.

Przyznano jej ordery i odznaczenia.

Moja samotność

jest uczęszczana.

Przechodzi przez nią parę tysięcy czytelników.

Jest zapisywana.

Skreślana.

Jest zmęczona rządzeniem

jak Fryderyk Wielki.

Zob. M. Bierdiajew Rozważania o egzystencji. Filozofia samotności i wspólnoty, przeł. M. Derewiecki, Antyk, Kęty 2013. S. 59.

P. Tillich Teologia systematyczna, t. 2, przeł. .. Marzęcki, Antyk, Kęty 2004, s. 48.

W tym miejscu ośmielam się przywołać nieco humorystyczną wypowiedź Ewy Lipskiej na ten temat, w której samotność przyrównana jest do cholesterolu. „Z samotnością zresztą trochę jest tak, jak z cholesterolem. Jest ta dobra samotność i zła samotność. Ja lubię korzystać z tej dobrej samotności. I wtedy bardzo często uciekam do takich miejsc, gdzie mogę się ukryć", www.youtube.com/watch?v=GK-TjmDjg6o. 
Zaczyna mieć już swoich wychowanków.

Nieśmiałych niewolników.

Moja samotność jest publiczna.

Leży na dnie klatki

z wyrwanymi lotkami ciszy. ${ }^{13}$

Tak opisywana samotność o zaskakujących cechach „punktualności” i,pilności", będąca obiektem nieustannego publicznego zainteresowania, łatwo identyfikowalna jako samotność artysty-literata, wydaje się de facto antysamotnością, parodią samotności, nie ma bowiem nic wspólnego z odosobnieniem i bezczasowością (niepodleganiem presji czasu naglącej teraźniejszości), z którymi zwykle kojarzy się stan bycia samotnym. Przyjmowana przez podmiotowość jakby beznamiętnie ingerencja innych („wielu” wobec „jednego", którzy „zapisują, , ,skreślają”, „przechodzą", ,uczęszczają” etc.) w sferę własnej prywatności, stanowiąca znak naruszenia integralności jednostki, wskazuje bez wątpienia na inercyjność podmiotu. Wrażenie niemożności działania potęguje strona bierna, która dominuje w dwóch pierwszych strofach: „przestrzeń samotności” bohatera utworu Lipskiej jest odwiedzana, oglądana, dotykana przez innych, zapisywana językowymi kodami nieprzynależnymi do niego samego.

„Mojość" takiego rodzaju (nie)samotności, sygnalizowana przez tytuł, oznaczać więc może usilne podmiotowe pragnienie posiadania samego siebie na własność - próbę wydarcia ja innym, z czym wiązać się ma osiągnięcie egzystencjalnej dojrzałości (opuszczenie „Szkoły Prymusów”, wyjście ze stanu „nieśmiałego niewolnictwa"). Reminiscencje Kantowskiego Co to jest Oświecenie nie są tu przypadkowe. Lipska, przywołując postać władcy Fryderyka Wielkiego oraz posługując się ograną, wyeksploatowaną w tradycji literackiej, figurą lotu (ewokującą np. mit o Ikarze, horacjańską identyfikację poety z ptakiem czy oświeceniową ideologię postępu/hegemonii „lotnego” rozumu), podejmuje wyjątkową grę z czytelnikiem. Zarzuca na niego sieci „klasycznej” metaforyki, by zmusić ukryty za konstruktem „swojej samotności" podmiot do wykrzyczenia własnego - niepodrabialnego, niekonwencjonalnego, idiomatycznego - sapere aude. Odwaga nie oznacza jednak w tym wypadku wiernopoddańczej postawy podmiotu wobec władz logosu, lecz umiejętność przemówienia prawdziwie własnym głosem - inicjację samodzielnego „zapisywania” i „skreślania” własnej egzystencji. 
To celowe, dekonstrukcyjne „pasożytnictwo na metaforach", jakiego dokonuje Lipska, (przypominające nieco nie-aktywność bohatera Schulzowskiej Samotności $\left.i^{14}\right)$, ma umożliwić podmiotowi wkroczenie w sferę indywidualizującego pisma, które, jak wiadomo, m.in. dzięki Jacques'owi Derridzie i Maurice'owi Blanchotowi ${ }^{15}$, oznacza śmierć prawdziwej (tj. pozatekstualnej) egzystencji. Język poetycki to przestrzeń pośmiertna, każdorazowa inskrypcja to żałobny epigraf, „wpismowstąpienie”16 równa się wkroczeniu na teren negatywności. Ja musi więc z konieczności dokonać autodestrukcji - samonihilacji - by stać się ( n i e ) ja. Tylko dzięki temu, paradoksalnie, może stać się w pełni sobą ${ }^{17}$. Nie chodzi jednak o przekaz wyświechtanego reklamowego hasła-sloganu Be yourself!. Gra nie toczy się tu o kupno-sprzedaż siebie, lecz o wynegocjowanie (wydedukowanie) siebie.

Taką właśnie drogę indywiduacyjnej negocjacji ja nakreśla w swoim eseju Negatywny platonizm Jan Patočka. W ujęciu czeskiego filozofa prawdziwa wolność egzystencjalna polega na zaangażowaniu, podjęciu ryzyka oraz radykalnym nieusatysfakcjonowaniu zastaną rzeczywistością. Negatywność (wiążąca się u Patočki z platońskim terminem chorismos pojmowanym jako separacja/oddzielenie wobec tego, co przedmiotowe/dane tu i teraz) okazuje się prawem naturalnego pragnienia człowieka do bycia-sobą i gwarantem autentycznej wolności. To wariant „buntu metafizycznego” Alberta Camusa (myśliciela skądinąd cenionego przez samą Lipską ${ }^{18}$ - buntu przeciwko nieuchronności praw egzystencji jako takiej, pozwalającego jednostce doświadczyć prawdziwej wolności:

"Należy to do właściwości mojej egzystencji, że pasożytuję na metaforach, daję się tak łatwo ponosić pierwszej lepszej metaforze. Zapędziwszy się tak, muszę dopiero z trudem odwoływać się z powrotem, wracając powoli do opamiętania". B. Schulz Samotność, w: tegoż Sanatorium pod Klepsydra, Warszawa 2013, s. 77.

Zob. np. A. Bielik-Robson „Na pustyni": kryptoteologie późnej nowoczesności, Universitas, Kraków 2008, s. 115-120.

Określenia Tadeusza Komendanta na określenie praktyki pisarskiej Michela Foucaulta (zob. tamże, s. 115).

Problematykę „bycia-sobą" podejmowali m.in. Søren Kierkegaard, Karl Jaspers, Martin Heidegger oraz francuscy egzystencjaliści, którzy podkreślali, że droga indywiduacji zakłada odrzucenie siebie (poprzez zaryzykowanie siebie/decyzję) jako podmiotu empirycznego (doświadczającego zmysłowo, ogólnego, "wewnątrzświatowego"). Człowiek zbuntowany Camusa (zob. np.: https://zwierciadlo.pl/kultura/kultura-wywiady/ewa-lipska-zycie-na-fali-buntu). 
$\mathrm{Na}$ czym polega więc doświadczenie wolności? Jest to doświadczenie nieusatysfakcjonowania tym, co dane i zmysłowe, doświadczenie, które stopniowo pojmuje, że to, co dane i zmysłowe nie jest wszystkim, ani tym, co decydujące. $Z$ tego też powodu dla doświadczenia wolności kluczowe są przeżycia „negatywne”, które ujawniają, że cała zawartość biernego doświadczenia jest nieistotna, tymczasowa, błaha. ${ }^{19}$

W Mojej samotności milczenie podmiotu oznaczałoby jednak zaprzeczenie tak ujmowanego gestu „niezadowolenia” - buntu wobec stanu faktycznego rzeczywistości. Podmiot milczący to $\mathrm{w}$ takim ujęciu podmiot zagadany. Jego afonia nie oznacza świadomego wyboru - gestu wyrażającego niemożność eksplikacji własnego doświadczenia. Ja z Mojej samotności milknie z przymusu. Wydaje się on jednak konieczny - otrzeźwiający, motywujący przez swoją negatywność - do podjęcia przeciwdziałania. Podmiot musi znaleźć się na „dnie klatki/z wyrwanymi lotkami ciszy”, by uświadomić sobie, że: „Milczenie zastępuje samotność, odgradzając nas od ludzi i chroniąc od małostek, które by wraz z treścią wypowiedzianych słów wtargnęły do duszy"20.

Tak pojmowane milczenie (jako nie-pisanie, konformizm, pasywność, poddaństwo, „nieśmiałe niewolnictwo") jest zatem jedynie ersatzem prawdziwej samotności, choć jednocześnie chroni podmiot od czczej gadaniny i bycia-zagadanym. Pozwala na odmowę dostrajania się do chóralnej „światowej” harmonii. Żeby wydobyć się ze stanu „niepełnoletniości”, potrzeba czegoś więcej. Bohater wspomnianego już opowiadania Schulza, podobnie jak podmiot Mojej samotności, pogrążony jest w stagnacji znamionowanej wszechobecną ciszą („Siedzę i słucham ciszy”21). Wie, że jedyną drogą wyjścia z klaustrofobicznej klitki („klatki” z wiersza Lipskiej) jest stworzenie - mocą własnej wyobraźni i woli - drzwi. „Nie ma pokoju tak zamurowanego, żeby się na takie drzwi zaufane nie otwierał, jeśli tylko starczy sił, by mu je zainsynuować" ${ }^{22}$.Trywialnie parafrazując zakończenie Schulzowskiej Samotności, można by stwierdzić, że nie ma takiego dna, z którego nie można byłoby się odbić i wybić na samodzielność.

J. Patočka Negatywny platonizm. O genezie, problematyce i zaniku metafizyki oraz pytaniu, czy filozofia może istnieć bez niej, "Kwartalnik Filozoficzny” 2005 nr 4, s. 189.

H. Elzenberg Kłopot z istnieniem..., s. 171.

B. Schulz Samotność, s. 76. 
Czy tę konieczność działania i wy(d)edukowania uświadamia sobie bohater wiersza Lipskiej? Oskubana z piór cisza musi przecież stać się mięsistym głosem-nielotem, stąpającym twardo po ziemi, niedającym się zdeptać przez tłum. Nie wystarczy szukanie po omacku wyjścia z sytuacji, trzeba to wyjście wymyślić, „zainsynuować”, wykreować, napisać. Ten wniosek wyciąga jednak już bohater innego utworu Lipskiej - prozy poetyckiej Samotność z późniejszego o trzy dekady tomu Miłość, droga pani Schubert. Czy jest on w stanie uwierzyć w powodzenie takiej aktywności? Wydaje się, że możliwość znalezienia schronu-samotni poprzez działanie w języku/poprzez język zostaje przezeń bardzo szybko podana w wątpliwość:

Droga pani Schubert, kiedy moje życie odpoczywa, odwieszam ocean. Rezygnuję z czujności słów, które mnie strzegą. Nie odzywam się do ucha. Ani do nikogo. Nie popiera mnie czas. Jest wciąż ta sama pora samotności, której nie ma, chociaż na boku coś tam sobie notuje, szkicuje, pisze kamień. ${ }^{23}$

Wjakim stanie znajduje się nadawca tego lirycznego listu? Czy przebył już drogę od nieautentycznego uspołecznionego ,ja” do piekła pisma? „Sytuacja pisania” nigdy nie jest przecież u Lipskiej wybawieniem, nawet jeśli je obiecuje. To tylko pozorny schron - jak zapewnia w swoim szkicu Wojciech Ligęza ${ }^{24}$.Poeta Lipskiej (Lipska-poeta?) żyje w nieodzownie tymczasowym "schronisku dla słów" ${ }^{25}$, nie może być pewny niczego. Jego egzystencjalny status określić można, za Anną Legeżyńską, jako permanentną bezdomnośćc6 lub, jak postuluje Grzegorz Olszański, atopijne bycie-gdzie-indziej ${ }^{27}$. Taka podmiotowość to coś w rodzaju Rimbaudowskiego JE est un autre („JA to ktoś inny”28) czy Baudelaire'owskiego

23 E. Lipska Samotność, w: tejże Miłość, droga pani Schubert.., Wydawnictwo Literackie, Kraków 2013, s. 30.

W. Ligęza Metafory i sytuacja pisania w poezji Ewy Lipskiej, w: „Stoję i patrzę na czym ten świat stoi”. O twórczości Ewy Lipskiej, red. W. Ligęza, A. Piech-Klikowicz, Wydawnictwo UJ, Kraków 2018.

E. Lipska Poeta, w: tejże Wiersze wybrane, s. 67.

A. Legeżyńska Dom i poetycka bezdomność w poezji Ewy Lipskiej, „Pamiętnik Literacki 1996 z. 1.

A. Dziadek Atopia - stadność i jednostkowość, "Teksty Drugie” 2008 nr 1/2; G. Olszański Napisz to jeszcze raz, Ewo. O motywie domu w twórczości Ewy Lipskiej - suplement, w: tegoż Apelacje. Szkice o literaturze i przygodach jej twórców, Instytut Mikołowski, Mikołów 2012. Zob. także: E. Lipska Gdzie Indziej, w: tejże Wiersze wybrane, s. 256.

28 A. Rimbaud /a to ktoś inny: korespondencja Artura Rimbaud, przeł. i oprac. J. Hartwig, A. Międzyrzecki, Czytelnik, Warszawa 1970. 
„ja wiecznie niesytego wszelkiego nie-ja"29, dążącego do autoalienacji i samozniszczenia, które wyzwalają od pozoru nieautentycznego n i e - ja (społecznego, wspólnotowego). Doświadczenie siebie jako (n i e) j a to konieczny etap w procesie negatywnej kryzysowej dedukcji. Jego miejscem jest właśnie pismo albo, ściślej rzecz ujmując, pisanie/zapisywanie, nie zaś bierne „bycie zapisywanym".

Co zatem oznacza gest rezygnacji z „czujności słów” w utworze Lipskiej? Czy to opis stanu po katastrofie pisma - po drugiej niewoli (tuż po poddaństwie wobec społeczeństwa) - w którym następuje błogi odpoczynek zarówno od hałaśliwej codzienności, jak i bezpiecznego kokonu strzegącej (nadzorującej? ograniczającej?) językowej komunikacji, której jedną ze szczególnych odmian jest poezja? Świat skonstruowany przez podmiot (poprzez język) i świat konstruujący podmiot (rzeczywistość zewnętrzna, relacje z innymi) zostają zawieszone („odwieszam ocean”), wokół nie ma nikogo innego (poza s a my m ja). Jakakolwiek komunikacja z rozwrzeszczanym światem zewnętrznym - szumiącym, zagłuszającym intymny głos ja „oceanem” wiadomości, plotek i fasadowych relacji - nie jest już konieczna. „Nie odzywam się do ucha", rejestrującego ową światową paplaninę - oznajmia podmiot Samotności. Platoniczny adorator pani Schubert oznajmia, że wreszcie odkrył sztuczkę, dzięki której można przechytrzyć czas. Jest nią quasi-stoicka ataraksja - obojętność na to, co zewnętrzne, czysta negacja bytów przedmiotowych i zwrot ku podmiotowemu byciu ja. Heideggerowska różnica ontologiczna i problematyzacja nicości (jako ostatecznego spełnienia Dasein - bycia-ku-śmierci) narzuca się tu automatycznie, podobnie jak, przywoływana już przeze mnie, koncepcja Patočki - wizja wolności jako doświadczenia negatywnego umożliwiającego wyłonienie się prawdziwego ja. Według niemieckiego, jak i czeskiego filozofa, doświadczenie tego typu łączy się jednak z podjęciem ryzyka, intensywnym zaangażowaniem, nie zaś, jak to wyżej zasugerowałem w odniesieniu do Samotności Lipskiej, niewzruszonością:

Wolność jednakże jest doświadczeniem zaangażowania, jest doświadczeniem ryzyka, za które można wziąć odpowiedzialność, ale któremu można się również wymknąć. [...] doświadczenie wolności jest doświadczeniem podboju, zdobycia wolności, a nie jej spokojnego posiadania ${ }^{30}$. obraz terytoria, Gdańsk 2000, s. 317. 
Samotność w utworze z tomu Miłość, droga pani Schubert nie jest już jednak bierna,jak w analizowanej wcześniej Mojej samotności. Jej obojętność to wyraz aktywności. To ona s a m a "na boku coś tam sobie notuje, szkicuje, pisze kamień”. Nie jest już „zapisywana” i „skreślana”, samodzielnie dzierży w dłoni pióro i zostawia ślady atramentu w otaczającej ją rzeczywistości („pisze kamień") oraz notatkach prywatnych - zapiskach nie na pokaz, przeznaczonych wyłącznie do użytku własnego. Dlaczego jednak podmiot zostaje oddzielony, niczym platońskim znakiem chorismos, od tak zaangażowanej samotności? Dlaczego sam pozostaje pasywny, nie potrafiąc zaryzykować siebie? Co stoi na przeszkodzie w jego zjednoczeniu się ze swoją samotnością (nawiasem: czy takie - na poły antropomorfizujące - ujmowanie samotności nie brzmi co najmniej dziwacznie)? Wreszcie: co oznacza fraza: „Jest wciąż ta sama pora samotności, której nie ma"? Czy istotą samotności jest nieistnienie (bycie wytworem wyobraźni) czy raczej niedostępność?

\section{Od toż-samości do samości}

Wydaje się, że nadeszła „pora”, by termin „samotność”, głęboko zakorzeniony w leksykonie Lipskiej, zastąpić czymś, co byłoby czytelniejsze dla interpretatora twórczości poetki i lepiej odpowiadałoby samemu konceptowi autorki Pomarańczy Newtona. Już po lekturze dwu analizowanych tu utworów trudno nie odnieść wrażenia, że Lipska używa pojęcia „samotności” w sposób nie tylko niezgodny z potocznym jej rozumieniem, ale również w pewnym sensie anakolutyczny czy alogiczny. Co tak naprawdę kryje się więc pod tą nazwą? Jakie znaczenia szyfruje „samotność" Lipskiej?

Myślę, że warto w tym miejscu przyjrzeć się polu semantycznemu „samotności", jakie nakreślił wybitny kanadyjski badacz loneliness studies John G. McGraw. Według niego do owego obszaru należą: „samość (aloneness), odosobnienie (solitude), osamotnienie (aloneliness), samotność (loneliness), samotniczość (alonism), samotnizm (lonism), samotnictwo (lonerism), odludność (reclusiveness), odseparowanie (seclusion), fizyczna i społeczna izolacja (isolation), pustelniczość (desolation) oraz solipsyzm (solipsism)" ${ }^{\text {31 }}$. Piotr Domeracki wymienia zaś w tym kontekście: „samość, sobość, odosobnienie, samotnictwo (resp. pustelnictwo), wyobcowanie oraz depersonalizację

31 P. Domeracki Horyzonty..., s. 88. Zob. J.G. McGraw Intimacy and Aloneness, t. 1: Intimacy and Isolation, Rodopi, Amsterdam-New York 2010, s. 17. 
(odosobienie)"32. Żadnego z tych określeń nie można traktować ani jako synonimu, ani hiponimu „samotności”, co można zauważyć chociażby w wyliczeniu McGrawa, w którym to termin „samotność” funkcjonuje na takich samych prawach jak inne pojęcia. Po powyższych typologiach widać również, jak daleko semantycznie lokują się wobec siebie rozmaite terminy. „Izolacja”, "odseparowanie" czy „osamotnienie" przywołują automatycznie negatywne konotacje (zakładając brak możliwości wyboru ze strony „samotnika”), podczas gdy np. „pustelniczość” wiedzie nas w stronę świadomej decyzji, ascetycznego trybu życia, pogłębionej duchowości itd. (podobnie jak „solipsyzm" czy "sobość" ewokujące filozoficzną proweniencję). Najmniej oczywiste wydaje się pojęcie „samości” brzmiące jak neologizm, najmniej obciążone kulturowymi (czy: socjologicznymi, filozoficznymi, religijnymi, a także: potocznymi) kontekstami.

„Samość" pojawiła się w polszczyźnie, m.in. za sprawą tłumaczenia Wacława Berenta Tako rzecze Zaratustra, w którym w rozdziale $O$ wzgardzicielach ciała pojawia się termin „das Selbst" ${ }^{\prime 3}$ :

Narzędziem i igraszką jest zmysł i duch, poza niemi jest jeszcze samość.

Samość szuka oczami zmysłów, słucha uszami ducha.

Zawszeć samość słucha i szuka: porównywa, zniewala, zdobywa i burzy. Panuje i jest też władcą jaźni.

Poza twemi myślami i uczuciami, bracie mój, stoi władca potężny, mędrzec nieznany - zwie się on „ty sam“. W twojem ciele on mieszka, twojem jest ciałem. ${ }^{34}$

„Samość" w koncepcji Nietzschego jawi się jako podmiotowa dyspozycja do bycia w pełni sobą, która pozwala jednostce na całościowe - psychofizyczne, afektywno-inteligibilne, zmysłowo-pojęciowe - doświadczanie świata i siebie samej. Zniesienie dualizmu (ciało-dusza, rozum-duch) dokonuje się właśnie w geście zaangażowanej indywiduacji. „Samość” to wreszcie instancja, która zmusza człowieka do nieustannej pracy przedefiniowywania własnej egzystencji - jednak nie w trybie językowej (pojęciowej) obróbki, lecz holistycznego (czy także, np. somatycznego) doświadczania. Owa redefinicja ja polegałaby, według

P. Domeracki Horyzonty...

Oryginał: www.nietzschesource.org/\#eKGWB/Za-I-Veraechter.

F. Nietzsche Tako rzecze Zaratustra, przeł. W. Berent, Towarzystwo Wydawnicze "Ignis", ToruńWarszawa-Siedlce 1922, s. 55. 
Nietzschego, na permanentnym autodekonstruowaniu, w której zawiera się element zarówno autodestrukcji, dekonstrukcji, jak i konstruowania. „Samość” bowiem „porównywa, zniewala, zdobywa i burzy” ludzką jaźń - jest jakimś n a d - j a (nietożsamym z Freudowskim superego), stanowiąc tę część osobowości (czy raczej: osobności), która byłaby odpowiedzialna za tzw. egzystencję autentyczną. Byłaby zarazem niedoścignionym wzorem jaźni (władającym nią i zmuszającym ludzi do, dosłownie, nad-ludzkiego wysiłku - tego, by „ponad samych siebie tworzyć" ${ }^{\prime 35}$ ). Powodowałaby jednocześnie nieustanne rozczarowanie ja samym sobą, poczucie wiecznego nienasycenia, ból fałszywości własnej egzystencji. Te natomiast negatywne uczucia (które Nietzsche ujmuje potem zbiorczą nazwą „bólu”36 - oryg. „der Schmerz") mają mobilizować jednostkę do ciąłego „nieusatysfakcjonowania” (o którym pisałem wcześniej).

Warto rozpatrzyć w tym miejscu kontekst umieszczenia koncepcji „samości” przez Nietzschego, tj. rozważyć związek „das Selbst” z ciałem („das Leib”). W cytowanym wyżej fragmencie $O$ wzgardzicielach ciała filozof pisze bowiem, że „samość” jest zarówno ciałem (domem) bycia, jak i zamieszkuje ciało, co oznaczałoby, że bycia-sobą nie można oddzielić od bycia-cielesnym/bycia-ciałem. Nietzsche krytykuje w całym rozdziale „wzgardzicieli ciała” - tych, którzy istoty człowieczeństwa upatrują w bezcielesnej duchowości i racjonalności. Jakie jednak konsekwencje ma ta krytyka dla konceptualizacji „samości”? Co oznacza dwuwektorowy, w pewnym sensie również: (samo)zwrotny, związek ja (w wersji: ult r a -ja) z własnym ciałem. Ewa Lipska w utworze Samotność pochodzącym z Czytnika linii papilarnych przygląda się podobnemu problemowi:

Samotność nie ma ciała.

Nawet kiedy nas obejmuje.

Jest zdradliwie pusta.

Jak pudełko po myślach.

Krąży nad nami

jak zwiadowczy samolot.

Cudem ocalała

spod koła umarłych

jest tym czym nie powinna być. ${ }^{37}$

Tamże, s. 56.

36 Tamże.

E. Lipska Samotność, w: tejże Czytnik linii papilarnych, Kraków 2015, s. 17. 
Dlaczego według Lipskiej „samotność” jest bezcielesna? Czy pierwszy wers tego utworu idzie w parze z teorią Nietzschego, czy pod prąd rozpoznań autora Jutrzenki? Drugi wers rozjaśnia nieco moim zdaniem tę wątpliwość. Bycie „obejmowanym" przez samotność przypomina bowiem Nietzscheańską metaforę ciała jako zarazem domostwa „samości” i obiektu jej autoidentyfikacji. To, co obejmuje, staje się wszak jednością z obejmowanym, będąc jednocześnie wciąż czymś oddzielnym/osobnym. Uścisk (jeśli jest obustronnie pożądany) daje poczucie bezpieczeństwa: bycia-w-domu. Z drugiej strony „samość" nie może w pełni posiąść („nie ma”) ciała drugiego (także w wariancie: swojego ciała). Może jednak w dalszym ciągu być ciałem - o czym jednak poetka nie pisze wprost, pozostawiając czytelnika z niejasnym sformułowaniem: ,jest tym czym nie powinna być”. Ta fraza jest być może jakimś przekształconym powtórzeniem „samotności, której nie ma" z analizowanej już przeze mnie prozy poetyckiej Samotność. Trudno się jednak nie zgodzić, że niebyt czy fikcjonalność samotności nie są tym samym, co niespełnianie przez nią wymogów/powinności stawianych przez jednostkę.

Czy zatem w wierszu z Czytnika linii papilarnych mamy do czynienia z podmiotem dojrzalszym, bardziej świadomym siebie, lepiej wyedukowanym i wydedukowanym z ogólności (Moja samotność), mającym za sobą doświadczenie śmierci w piśmie (Samotność z Miłości, droga pani Schubert...)? Inaczej: czy droga od toż-samości (rozumianej etymologicznie: jako identyfikacja z czymś, bycie takim samym jak coś/ktoś, zakładające niwelowanie wszelkich różnic ${ }^{38}$ ) do samości (bycia samym sobą z zachowaniem inności/odrębności/ niespójności ja) została już przebyta? Jeśli odpowiedź na to pytanie jest twierdząca, to dlaczego "samotność" Lipskiej nie spełnia oczekiwań j a? Czy nie powinniśmy odwrócić tego pytania, tzn. zapytać dlaczego ja nie jest wciąż zadowalające dla „samotności”?

W tym miejscu trzeba wrócić do podstawowego zadania, jakie jaźni dążącej do bycia nad-jaźnią, wyznacza Nietzsche. Jest nią nieustanna autodekonstrukcja - ciągła praca Aufhebung: znoszenia siebie (również w znaczeniu: wytrzymywania z nie-znośnym sobą) i budowania na nowo. Stąd nieustannie podejmowana przez podmiot próba wpisania własnego doświadczenia w „metafizyczną krainę samotności” - poezję (ze świadomością jej śmierciodajnego charakteru). Moment jakiejkolwiek stagnacji oznacza powrót do stanu początkowego, czyli nieposzczególności. Trzeba przy tym nieustannie

38 Por. z rozróżnieniem na "Toż-Same” $i$ „Inne” w filozofii Emmanuela Lévinasa (tegoż Czas i to, co inne, przeł. J. Migasiński, Wydawnictwo KR, Warszawa 1999). 
pamiętać, że „samotność”, jak pisze Lipska, jest „zdradliwie pusta” - zwodzi podmiot, symulując, iż problem egzystencjalnej autentyczności został rozwiązany, wszystko zostało już wy-myślone: zostaje tylko „pudełko po myślach”. Jednostka musi sobie uświadomić, że „samotność”, tak jak Nietzscheańska „samość”, jest niestrudzonym katem podmiotowości - „zwiadowczym samolotem”, instancją władzy nad jaźnią - czymś, co nie pozwala na pełne samozadowolenie. „Największa rzecz to umieć należeć do siebie”39, głosi Montaigne w eseju $O$ samotności - rzecz, dodaje Lipska, nieosiągalna przez nie-nadczłowieka.

W utworze Tak samo Lipska formułuje bowiem następującą myśl: „Człowiek to taki zwykły człowiek: / potrafi zżyć się nawet z sobą"40. To zaskakujące dla podmiotu tego wiersza utożsamienie się człowieka z samym sobą - dotarcie przezeń do źródeł własnej podmiotowości (by posłużyć się określeniem Charlesa Taylora ${ }^{41}$ ) - nie oznacza jednak jego pełnej autoidentyfikacji. Projekt mocnego, samoświadomego, ,pewnego siebie podmiotu"42 - o proweniencji nowożytnej - jest mrzonką, co udowodnili dwudziestowieczni myśliciele filozofii inności ${ }^{43}$. Mimo że tytuł wiersza sugerowałby taką interpretację (podmiot jako identyczny,,,taki sam” jak jego świadomość siebie, pozbawiony jakichkolwiek wątpliwości na temat swojego j a), to warto zauważyć, jakiego czasownika używa Lipska, precyzując tę relację. „Zżyć się” ze sobą to nie, nomen omen, „to samo”, co zidentyfikować się ze sobą. „Życie” stoi tu po stronie całościowego (a nie jedynie rozumowego/duchowego) doświadczenia. Lipska z pewnością nie jest więc „wzgardzicielem ciała”.

Ten przykład miał za zadanie wesprzeć moją tezę, zgodnie z którą w filozofii samotności Lipskiej nie ma miejsca na twardą, dobrze ugruntowaną, statyczną tożsamość. Osiągnięcie identyfikacji z samym sobą nie jest tu ani możliwe, ani pożądane. Pozostaje więc naga „samość”, której krewnymi są „nieusatysfakcjonowanie”, ,niepowodzenie”, „pustość”, ,zdrada”, ale również

39 M. de Montaigne Próby, przeł. T. Boy-Żeleński, Wydawnictwo Ktoczyta.pl, Warszawa 2017, s. 340 .

40 E. Lipska Taksamo, w: tejże Wiersze wybrane, s. 89.

41 Chodzi oczywiście o jego monumentalną pracę Źródła podmiotowości. Narodziny tożsamości nowoczesnej.

42 J. Beaufret Heidegger a Nietzsche: pojęcie wartości, przeł. S. Cichowicz, P. Kamiński, „Teksty: teoria literatury, krytyka, interpretacja" $1980 \mathrm{nr}$ 3, s. 113.

43 Do których zalicza się m.in. Emannuela Lévinasa, Jacques'a Derridę, Gilles'a Deleuze'a czy Michela Foucaulta. 
- co ciekawe - „ocalenie”. Warto bowiem pamiętać, że to właśnie „samotność" cudem wymyka się śmierci (tu rozumianej jako wpadnięcie w pułapkę nieautentyczności). To dzięki niej ja wydobywa się „spod koła umarłych”, otrzymując kolejną szansę podjęcia syzyfowej (niedorywczej) pracy dźwigania swojej egzystencji - wtłaczania głazu „samotności” w kołowrotek konstrukcji i destrukcji.

\section{Próba podsumowania: ku (od)osobnieniu}

Nie ulega wątpliwości, że opisywany w poprzednim rozdziale sposób rozumienia przez Lipską „tożsamości” i jej wyzwolonego od autorytarnych władz logosu wariantu - „samości” - jest tematem wciąż obecnym i na nowo podejmowanym w twórczości autorki Sefera. W quasi-alegoryczny sposób przedstawiła Lipska kompromitację konstruktu mocnej tożsamości w dramacie Nie o śmierć tutaj chodzi, lecz o biaty kordonek, której akcja rozgrywa się w „życiu po życiu”, jeden z bohaterów nazywa się zaś Idem (dosł. „to samo”, "ten sam”, zatem można go potraktować jako figurę kartezjańskiej mocnej tożsamości).W poszukiwaniu niedokonanej samoświadomości i „utraconego czasu" toczy on zażarte dyskusje z Profesorem Tempusem, który w jednej ze swoich wypowiedzi tak podsumowuje idealistyczne losy swojego rozmówcy: „Czasami miewa napady wyobraźni [...] przez wiele lat rządził samotnością. Przez roztargnienie umarł dla ideałów"44. Jak już wiemy z lekcji Nietzschego, to nie człowiek włada samotnością („samością”), lecz ona jest „władcą jaźni". Pozór panowania nad samym sobą, bycia sobą w pełni zostaje Idemowi uświadomiony w stanach irracjonalnych, w których do głosu dochodzi to, co „nielogiczne” (afekty, fantazje, sny uaktywniające się w obecności Pana Drima - Pana „Marzyciela”). „Napady wyobraźni” to przypomnienie straconej okazji Idema na ucieczkę przed pułapką zawierzenia projektowi tożsamości jako bycia skończonego, totalnego, jasno określonego, zamkniętego na wszelką inność (jakiekolwiek n i e - j a). To wspomnienie jego śmierci pod „kołami umarłych" - bolesne wypominki wejścia na ścieżkę fałszywej indywiduacji, drogę egzystencjalnej indukcji: regresu od poszczególności do ogółu.

Losy podmiotowości rozmaitych utworów Lipskiej są jednak każdorazowo idiomatyczne - trudno je sprowadzić do ujednolicającego wzorca. Uproszczenie, którym posłużyłem się w tym szkicu, przyglądając się nieco bliżej jedynie trzem dziełom poetki oraz uruchamiając tylko kilka kontekstów, z pewnością

E. Lipska Nie o śmierć tutaj chodzi, lecz o biały kordonek, "Dialog” 1981 nr 5, s. 33. 
spłyca złożoność konceptualnego imaginarium autorki Miłości w trybie awaryjnym. Gdybym jednak miał podsumować dotychczasowe rozważania nad problemem „samotności", z jakim nieustannie mierzą się bohaterowie światów Lipskiej, a który, co starałem się wykazać, nie jest powtórzeniem ani romantycznej koncepcji artysty-samotnika, ani modernistycznego gestu artystowskiej (dandysowskiej) dystynkcji, posłużyłbym się poetycką nomenklaturą Krzysztofa Siwczyka, o którego najnowszym tomie wspominałem na początku tego studium. W Osobnikim (Osobnikcie?) poeta tworzy koncept tożsamościowego „osobnienia” - wydobywania się jednostki z otchłani ogólności ku „osobnemu" indywiduum - w wielu aspektach zbieżny z pomysłami Lipskiej. Można zatem metaforycznie uznać, że przechodzenie od ogółu do szczegółu/dedukowanie ja w wierszach Lipskiej przebiega w trzech etapach, które nazwę za metaforami Siwczyka.

1) Pierwszą fazą tego procesu jest „odosobnienie" 45 zaprezentowane przez Lipską w Mojej samotności, w której podmiot musi odseparować się od zewnętrznej rzeczywistości, odciąć od swojego uspołecznienia, by zainicjować twórcze działanie (odrzucając bierne podleganie egzogennemu „zapisywaniu" i „skreślaniu" - konstruowaniu przez innych - własnej egzystencji), by przestać bezwiednie powtarzać za głosem „prawdy obiektywnej"46 i zacząć mówić głosem subiektywnym ${ }^{47}$.

2) Następnie ja oddzielone od doświadczenia uwspólnionego/niejednostkowego wkracza w sferę twórczości (która u Lipskiej najczęściej oznacza twórczość literacką, może jednak oznaczać jakąkolwiek formę podmiotowego działania $\left.{ }^{48}\right)$. Wyraża brak usatysfakcjonowania tym, co oferuje mu zastana rzeczywistość. Buntując się przeciwko własnej egzystencji, podmiot odkrywa

K. Siwczyk Odosobnienie, w: tegoż Osobnikt, s. 31.

Taki tytuł ma utwór, który Siwczyk poświęcił Lipskiej. K. Siwczyk Prawda obiektywna, w: tegoż Osobnikt, s. 33 .

Trzeba od razu zaznaczyć, że nie jest to tożsame z brakiem chęci jakichkolwiek relacji z innymi. Wręcz przeciwnie, podmiotów prezentowanych w wielu utworach Lipskiej nie można nazwać odludkami, są one ukierunkowane na kontakt z innym, łakną przyjaźni/miłości, co wykazała w swojej monografii „Patrzymy sobie w oczy...". O twórczości Ewy Lipskiej Aneta Piech-Klikowicz, wykorzystując w swej interpretacji m.in. zdobycze filozofii dialogu oraz filozofii inności Emmanuela Lévinasa, siebie. Zob. H. Arendt Działanie, w: tejże Kondycja ludzka, przeł. A. Łagodzka, Warszawa 2010. 
w sobie samym potencjał negatywności - to "osobnikt"49 - (n ie) ja zmuszone do zaakceptowania śmiercionośnego charakteru „wpismowstąpienia" i ciągłej nieufności względem samego siebie („Nie wierz sobie, wszystko, co będzie tobą, musi minąc'"50). Dzięki temu może jednak prawdziwie zwrócić się ku sobie samemu (by móc stać się „osobkimś”).

3) Następuje "pora samotności, której nie ma” - czas próby, ryzyka, kryzysu. „Osobnikt” dostrzega możliwość „osobnienia”"51 (który Siwczyk opisuje jako akt narodzin/wydania na świat - wrzucenia-w-świat). Chce po Nietzscheańsku „tworzyć ponad siebie”. Cechuje go poznawcze nienasycenie i egzystencjalny niepokój. Proces docierania do własnej samotności („samości") nie może się jednak zakończyć. Podmiot coraz bardziej zdaje sobie sprawę, że stworzenie trwałej tożsamości (czyli pełnej samoświadomości) nie jest możliwe. Pozostaje mu zaakceptowanie swojej niezbywalnej obcości oraz konieczności nieustannej autodekonstrukcji siebie - zgoda na niezbywalny „kłopot z istnieniem”. Przejawem tego niezacieralnego rozdzielenia/ napięcia i, jednocześnie, pragnienia/pożądania, (ni e) ja podmiotowego i ponadpodmiotowego $\mathrm{n}$ a d-ja jest poetyka trzecioosobowego mówienia o samotności („samości”) jako czymś o s o b ny m - oddzielnym od samej jednostki.

Jedyne, co zostaje badaczowi kłopotu Lipskiej z „samotnością” czy raczej „samością"/osobnością, jest również nolens volens zgoda na nierozwiązywalność tego problemu. Taka postawa daje jednak tylko chwilowe poczucie bezpieczeństwa, bo wiadomo, że w świecie autorki Pamięci operacyjnej „schron niczego nie obiecuje", a „samotni [są obecni - przyp. S.B.] na wszystkich frontach"52 - nie da się ich (na szczęście!) interpretacyjnie spacyfikować. Wciąż domagają się usłyszenia swoich cichych, lecz znaczeniowo doniosłych (donośnych), głosów.

K. Siwczyk Osobnikt, s. 26.

Tamże, s. 26-27.

K. Siwczyk Osobienie, w: tegoż Osobnikt, s. 12. 


\section{Abstract}

\section{Sebastian Brejnak}

JAGIELLONIAN UNIVERSITY (CRACOW)

Ewa Lipska's Problem with Loneliness: From Generality to Detail; or, The Deduction of the Self

Brejnak examines the logic of loneliness in three poems by Ewa Lipska which address the problem of"loneliness" in their titles. Lipska's use of the term "loneliness,"Brejnak argues, denotes the subject's striving to overcome zdezindywidualizowanej ogólności and attain authentic and individual existence. This path of metaphysical deduction is performed through an entry into the sphere of writing and a transgression of this sphere in a gesture of self-annihilation. Drawing on Nietzsche's notion of das Selbst and Jan Patočka's concept of the experience of freedom, Brejnak concludes that Lipska's "loneliness" is a project of self-deconstructive"loneliness" - of a subject"unsure of itself," perpetually constructing and destroying its own identity-forming self.

\section{Keywords}

Ewa Lipska, loneliness, identity, subject, subjectivity, the self, separateness, poetry, Polish poetry, contemporary poetry, Nietzsche, existentialism, existence 